\title{
He who laughs last - Jesus and laughter in the Synoptic and Gnostic traditions
}

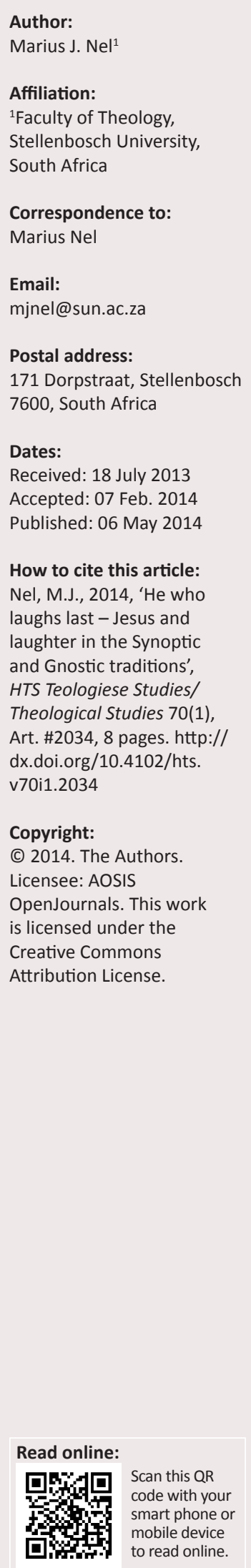

The aim of the article is to examine the meaning of references to laughter in the Synoptic Gospels and number of Gnostic texts. Whereas Jesus is depicted as an object of ridicule (Mk 5:40 par.) and as condemning those who laugh in the Synoptic Gospels (Lk 6:25), it is he who often laughs derisively at the ignorance of others in Gnostic texts. The meaning of laughter in the Synoptic Gospels and a number of Gnostic texts is examined in the light of the general Greco-Roman attitude towards laughter and, more specifically, in regard to the archetypical distinction between playful and consequential laughter in Greek culture.

\section{Introduction}

In the Synoptic Gospels, Jesus not only never laughs, but he also explicitly warns those who do that their laughter will turn into mourning and weeping (Lk 6:25b). Whereas early and medieval Christian theologians, who tended to be solemn and serious themselves, could identify with a Jesus who weeps but never laughs (cf. Berger 1997:198-199; Gilhus 1997:12-13), ${ }^{1}$ the same cannot be said of a number of modern Western interpreters of the Gospels who live in a culture in which the social status of laughter and humour has been dramatically reappraised (cf. Billing 2005:10-33). ${ }^{2}$ As a result of this reappraisal of laughter as healthy for both the individual and for society, the antigelastic Jesus has been re-evaluated, resulting in him being depicted in art, sermons and literature as being humorous, smiling and even laughing (cf. Berger 1997:198; Geybels 2011:11; Longenecker 2008:194-204). Behind this quest for a laughing Jesus is the unspoken assumption that laughing would enhance his humanity as humour and laughter are understood to be uniquely human traits (cf. Berger 1997:45-64).

The reappraisal of laughter, and of Jesus' relation to laughter, ${ }^{3}$ emphasises that, whilst laughter is a universal human expression, its meaning and function are always culturally determined (Apte 1985:257). ${ }^{4}$ This article, therefore, seeks to explore the social and rhetorical function of references to laughter as it relates to Jesus in the Synoptic Gospels and a selection of Gnostic texts within the context in which they were written. As references to laughter is used as a rhetorical device by some Greek writers (e.g. Herodotus) in order to give their readers insight into the character of those they write about (Lateiner 1974:173-174), references to laughter relating to Jesus can provide some insight into how the authors of the Synoptic Gospels and a number of apocryphal texts understood Jesus differently, for contra the Synoptic Gospels, he laughs repeatedly in certain Gnostic texts. It is this laughing Jesus that some scholars argue is better aligned with the contemporary reappraisal of Jesus as a more approachable figure than the laughterless Jesus of the Synoptic Gospels (cf. Krosney 2006:286; Longenecker 2008:180). The question thus arises not only if Jesus is depicted as laughing or not in various texts, but also how laughter was implicitly evaluated in the various communities reflected in the various texts as this could provide a valuable insight into the nature of these communities.

The focus of this article is on laughter and not humour. It is important to note that whilst the spheres of laughter and humour intersect, they do not overlap completely. Every instance of

1.Berger (1997:198) admits that the search for comic laughter in the Bible only succeeds if one engages in 'rather laboured interpretations' as laughter is, at best, rather implicit than explicit therein. See Halliwell (2008:476-479) for the possible presence of laughter in different forms of verbal expression in the New Testament and Bednarz (2009) for the occurrence of humour in the Synoptic Gospels.

2.According to Wickberg (1998:18), it was only in the 1840s that the concept of 'a sense of humour' started to be used and only by the 1870 s with the modern sense as an indication of a personality characteristic.

3.In a study conducted by Bennett (2011:349-356) to examine how contemporary Christians describe the humorous (or not) behaviour of Jesus, he used the Humorous behaviour Q-sort deck, and the statements that 'Has a good sense of humour' and 'Has the ability to tell long complex anecdotes successfully' earned the highest mean ratings. The statements 'Has an infectious laugh that starts others laughing' and 'Maintains group morale through humour' found their way into the third and fourth positions, respectively. The others laughing' and 'Maintains group morale through humour' found their way into the third and fourth positions, respectively. The
statement 'Finds intellectual word play enjoyable' also rated highly. The conclusion of the study is that the reappraisal of laughter in contemporary culture contributes to an understanding of Jesus as a figure who displayed the very human behaviour now described as a sense of humour.

4.Apte (1985:260) notes that laughter, from an anthropological perspective, is generally restrained in accordance with sociocultura norms of propriety because it often has derogatory and aggressive connotations. Cultural norms regarding the appropriateness of laughter depend on a number of factors such as social situation, age, sex, social status of participants and their relationship. 
laughter is not a response to humour, ${ }^{5}$ nor do all attempts at humour evoke laughter (Apte 1985:239; Gilhus 1997:3). This article will thus not seek to determine if the representation of the deeds and words of Jesus in various gospels would have been regarded as humorous by their intended readers (cf. Bennett 2011:349-356) or if the historical Jesus had a sense of humour (cf. Hand 2013:119-127) Nor does it focus on onomatopoeic expressions of laughter that may occur therein. ${ }^{6}$ Its focus is rather on references ${ }^{7}$ to laughter in the Synoptic Gospels (Mt 9:24; Mk 5:40; Lk 6:21b, 25b, 8:53) and a selection of Gnostic texts (The Infancy Gospel of Thomas, The Gospel of Judas, The Coptic Apocalypse of Peter and The Second Treatise of the Great Seth). ${ }^{8}$

The focus of this article is furthermore on the meaning, and not the cause, of laughter. Laughter as a phenomenon has been the object of study in several fields (e.g. philosophy, social science and psychology) that has resulted in three main theories about the causes of human laughter (Gilhus 1997:5). The superiority, incongruity and relief theories, ${ }^{9}$ however, do not explain the cultural meaning of laughter as they approach laughter as a universal phenomenon. The primary focus of this article is on the meaning of laughter in the Gospels as a culturally determined phenomenon (primarily in the GrecoRoman culture). Since some of the extant texts that refer to the laughter of Jesus are not in Greek but in Coptic, this article does not undertake a word study of Greek words for laughter (e.g. $\gamma \varepsilon \lambda \alpha \dot{\alpha} \omega) .{ }^{10}$ Whilst the documents on which this article will focus are not all in Greek, they are all based on Greek originals that originated in the Greco-Roman world. The references to laughter in them will therefore be studied in the light of the prevailing Greco-Roman ${ }^{11}$ attitude towards laughter.

5.Laughter can, for instance, also be caused by the stimulation of the body (e.g. through tickling) (Gilhus 1997:2-3) or be understood as an expression of the primordial human emotion of sheer joy (Apte 1985:239).

6.The occurrence of laughter injections in Greek literature is rare. After investigating laughter interjections in Greek comedy, Kidd (2011:445-459) comes to the

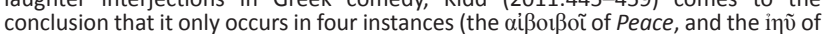
Acharnians, Peace and Wasps).

7.A distinction has to be made between texts that report the laughter of certain characters and comic texts that also aim to evoke laughter in their readers. The focus of this article is on the first.

8.Explicit references to the mocking of Jesus will not be examined as the social function thereof is narrower than that of laughter which is not necessarily derisive (cf. Halliwell 2008:471-476).

9.The superiority theory holds that the stimulus of the comic exists in the enjoyment of feeling superior to the other (Shelly 2003:352). The true object of laughter is the flaw in the other (for example their self-ignorance or inferiority). Laughter is thus a negative expression directed at someone. Relief theory argues that humour is connected to the relief one feels when some of the numerous restrictions governing connected to the relief one feels when some of the numerous restrictions governing
social life are temporarily lifted and built-up emotions are released. Laughter, in this social life are temporarily lifted and built-up emotions are released. Laughter, in this instance, expresses joy and relief. Incongruity theory, which is cognitive in nature understands the absurdity of contradiction to be the object of humour (Perks 2012:120). Laughter is therefore seen as a response to a humorous event or to that which is incredulous. Of these different theories, it is commonly claimed that the Greeks and Romans only knew of the superiority theory (cf. Taels 2011:23). Perks (2012:119-132) has, however, argued that this claim is reductive since, although Greek and Roman philosophers do provide the most support for the superiority theory, elements of all three major motivational theories of humour are found in the works of philosophers like Plato, Aristotle, Cicero and Quintilian.

10.Louw and Nida (1989:135-125) state that Greek, like most languages, clearly distinguish between three types of laughter: (1) laughter directed against some person as a form of ridicule (2) laughter resulting from seeing some humorous person as a form of ridicule, (2) laughter resulting from seeing some humorous event or as the result of listening to a humorous account and (3) laughter which reflects happiness and joy. Although not explicitly stated by Louw and Nida, thei theories that attempt to explain the causes of laughter.

11.For an overview of humour and laughter in the writings of Jewish authors (Josephus and Philo), see the study of Bednarz (2009:105-121).

\section{Laughter in Greco-Roman culture}

The modern understanding of laughter in the Greco-Roman world has been largely based on the evaluation thereof by Plato. Writing about laughter and malice, and how they are combined when an audience is laughing at a character being derided on stage or when a person is being ridiculed in public, Plato warns that laughter can be negative not only for the person being laughed at but also for the persons doing the laughing since they could come to prefer ridicule over reflection (Bednarz 2009:59-62; Shelly 2003:352). As other classical writers like Aristotle, Cicero and Quintilian also generally agreed with Plato that laughter was a form of behaviour from which civilised man should shrink, it has become common to state that the classical Greco-Roman approach to humour and laughter was predominantly negative (Berger 1997:19).

Recent studies (e.g. Perks 2012; Shelly 2003) on classical views of humour and laughter, however, argued that laughter was not always evaluated negatively. Laughter was rather seen as a fitting and effective response to certain exigencies by a number of Greek and Roman writers (Perks 2012:129). A more nuanced understanding of humour and laughter in the Greco-Roman world is thus necessary. In this regard, Shelly (2003) reappraised Plato's view of laughter and humour. In Philebus (49a-50a), Plato writes that when people observe something laughable, they simultaneously experience a mixture of the pain of malice and the pleasure of laughter. By implication, Plato views laughter as good, at least insofar as it restores the soul to health by balancing the ill feelings of malice with the pleasure of laughter. A balanced state, in which pain and pleasure counteracts each other, leaves the body in a calm, orderly state that frees the intellect from distractions. Laughter can thus be a positive pleasure that results in this desired state. It is, however, as with eating and drinking (that should seek to balance the pain of an empty stomach with the pleasure of eating), difficult for people to do in moderation. The problem with laughter is that it is not easy to laugh only enough in order to restore the balance of the body and mind. Laughter can easily become uncontrolled and is therefore classified in Philebus (52c-d) with things that are unlimited (i.e. difficult to measure) (Shelly 2003:354).

Whilst laughter can thus, according to Plato, have negative results for both the object as the subject thereof (Bednarz 2009:198-201), it can also be a positive bodily experience if done in moderation. All references to laughter in GrecoRoman text should therefore not automatically be assumed to be of a negative nature. ${ }^{12}$ In this regard, Halliwell (1991) attempted to give a more nuanced categorisation of humour in Greek literature. ${ }^{13}$ In his analysis of the extensive Greek vocabulary (at least 60 word-groups) that can express

12.References to laughter in Greek and Roman texts often have a specific rhetorical aim. Lateiner (1974:173-174), for instance, gives numerous examples of the use of laughter as a specific literary device in the writings of Herodotus that reveal that, whilst laughter can indicate simple relaxation and happiness, it was also used to communicate either the disdain of a character for others or to revea their self-assured scornful pride. In the last instance, laughter served as a literary prefiguration tha informed the reader that a chara le literary prefiguration that informed the reader that prosperity) had lost all sense of his or her vulnerability and was approaching their
demise.

13. Halliwell (1991:283-284) acknowledges that attempts to categorise laughter may in practice escape clear-cut definition for it 'has an intrinsic capacity to breach limits imposed upon it as moralists from Plato onwards have often observed'. 
laughter in a wide range of ancient Greek sources, ${ }^{14}$ Halliwell (1991:280) argued that a fundamental polarity existed between two archetypical Greek attitudes towards laughter. He defines these two archetypes as playful laughter and consequential laughter. ${ }^{15}$

Playful laughter is defined by the notion of play. ${ }^{16}$ It is indicted by the language of $\pi \alpha i \zeta \varepsilon v v, \pi \alpha 1 \delta i \alpha$ and $\pi \alpha i \gamma v i$ in and is sometimes in direct contrast to $\sigma \pi 0 v \delta \alpha$ Ão $\varsigma$ and $\sigma \varepsilon \mu v$ ó $\varsigma$, amongst others. The Greek word for play, $\pi \alpha \iota \delta i ́ \alpha$, is, according to Halliwell (1991):

... etymologically cognate with [ $\pi \alpha \tilde{s} \varsigma]$, 'child', and the connection helps to delimit the significance of playful laughter as something ideally innocent (both ethically and in the sense of make-believe) as well as self-contained. (p. 238)

As playful laughter was regarded by the Greeks as both necessary and desirable, cultural practices made provision for its shared enjoyment (Halliwell 1991:285-286).

The phrase consequential laughter refers to the various ways in which Greek texts recognise the capacity of laughter to become implicated in the practical (Halliwell 1991:280). Consequential laughter can have negative or positive consequences and is thus marked by its intention of accomplishing a definite result other than autonomous pleasure. ${ }^{17}$ It often arouses feelings 'which may not be shared or enjoyed by all concerned, and which typically involve some degree of antagonism' (Halliwell 1991:280). ${ }^{18}$

These two categories of playful and consequential laughter are interdependent and mutually clarifying. An essential characteristic of the notion of play is precisely an exemption from the sphere of practical effects and repercussions. In contrast, consequential laughter is experienced or judged as influencing the processes of personal and social relationships beyond the immediate context. Characteristics that are associated with playful laughter ${ }^{19}$ are correspondingly absent from consequential laughter. These characteristics, however, make playful laughter a potentially unstable and problematic category as what starts as playful laughter that is shared by all can easily result in laughter that has serious

14. References to laughter occur in Greek comedy, philosophy, oratory and history (Halliwell 1991:280). It varies from the most innocent smiles (Eur. Meda 1162) to harmless human amusement (II. 23.784) and the untroubled and fearless laughter of the gods (II. 1.599; Od. 8.307; Aesch. Eum. 560) to the cruel mockery that meets Cassandra (Aesch. Agam. 1264, 1271) and obsesses Sophocles's heroes (Ajax 79, 303, 367; OT 1422; OC 902) (Lateiner 1974:173).

15.Whilst this contrast overlaps with the general antithesis between $\gamma \varepsilon \lambda_{0} \tilde{A} 0 \varsigma$ and $\sigma \pi \mathrm{ov} \delta \alpha \tilde{A}$ os, it is not identical to it (Halliwell 1991:280).

16.For examples of playful laughter in Greek literature, see Halliwell (1991:280).

17.Consequential laughter can cause embarrassment or shame, signal hostility damage a reputation, contribute to the defeat of an opponent or deliver a public chastisement. It utilises a range of ridiculing tones that range from mild derision to the outrageously offensive (Halliwell 1991:283)

18.In the words of Aristotle: 'The persons with whom we get angry are those who laugh, mock, or jeer at us for such conduct is insolent' (Rhetoric 2.379b) whilst Plato states: 'When we laugh at what is ridiculous in our friends, we are mixing pleasure this time with malice, mixing, that is, our pleasure with pain' (Philebus 49e-50a).

19. Halliwell (1991:283) lists a number of characteristics of playful laughter: (1) a lightness of tone, (2) autonomous enjoyment, (3) psychological relaxation (4) and a shared acceptance of the self-sufficient presuppositions or conventions of such laughter by all who participate in it. consequences..$^{20}$ Once playfulness is exceeded, laughter is invariably regarded in Greek texts as having a human target on which it intends to effect pain, shame or harm (either in person or through the degeneration of his or her reputation and social standing) (Halliwell 1991:282-283).

Although playful laughter can have consequences, even if it does not intend to have any, it is intentional consequential laughter which is specifically used in societies characterised by a strong sense of honour and shame to express antagonism. In such societies, like those that comprised the Greco-Roman world, denigrating and scornful laughter function as the necessary corollary of praise and honour as a powerful means of conveying dishonour (Bednarz 2009:2). ${ }^{21}$ To mock or insult a person by laughing at him or her is an undeniable public challenge of their identity in order to denigrate his or her status. It is the intention to (usually negatively) impact the reputation and social standing of a person which is the primary determinant of consequential laughter's significance (Halliwell 1991:283, 286-287).

It was especially the open and public vilification that was feared the most, and it is thus not unexpected that the derisive laughter by an individual or group that expresses contempt for a character is a common motif in tragedy (Lateiner 1974:173). The power of laughter to publically shame someone in an honour and shame culture should not be underestimated. Quintilian, for example, describes laugher as a biting punishment for deviance. He states that 'what is said or done foolishly, angrily, fearfully, are equally the objects of laughter; and thus the origin of it is doubtful, as laughter is not far from derision' (Institutes VI.III.7). In the Greco-Roman world, derision from one's foes, making one

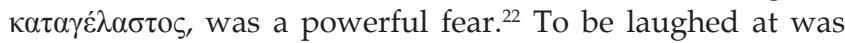
a serious affront that demanded that the object of derision respond appropriately to safeguard his or her honour. One who can tolerate being laughed at in public is aberrant enough to earn a place amongst Theophrastus' Characters (Halliwell 1991:287). The essential point, that ridicule can function as an act of aggression and real harm, is also reflected in the common pairing of abusive laughter with $\tilde{\beta} \beta \rho \varsigma^{23}$

The analysis of Greek laughter by Halliwell provides an indication of the varied social functions laughter can fulfil in the Greco-Roman word:

- Playful laughter: if shared with others, can signify the social acceptance of people as part of an in-group. The playful laughter of an individual in moderation can also positively signify his or her joy. If done in excess, it can negatively signify their lack of control.

20.The idea that what starts as verbal badinage may end in physical blows is something of a Greek topos (Halliwell 1991:284).

21.Plato, for instance, judged laugher to be a vehicle of 'ridicule and contempt' (Republic 5.473.c).

22. As a testimony to the power of laughter the words of Euripides' Megara should be noted that the laughter of one's enemies was worse than death itself (HF 285-286).

23.The emotional content of scornful or insulting laughter was sometimes identified

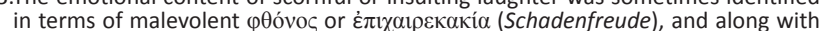
abuse and ridicule in general, it could be regarded as acts of harm, even üßpis because of their potential to cause shame (Halliwell 1991:289). Aristotle, in EN 1131a9 and Pol. 1262a27, includes defamation and abuse in a list of acts of $E N$ 1131a9 and Pol. 1262a27, includes defamation
violence, together with assault, murder and robbery. 
- Consequential laughter: as a force of real social potency is capable of sustaining values by inducing conformity to them. Alternatively, it can have a subversive and disruptive function in that it can undermine the values of a group or society (cf. Halliwell 1991:286). Greek and Roman philosophers were also aware of the fact that, whilst laughter may be a powerful mechanism of social control, rhetors could also harm their own ethos by engaging in jest and derisive laughter (Perks 2012:127). Laughter can thus have social consequences for both the subject and the object thereof (Bednarz 2009:97).

\section{Laughter in the Synoptic Gospels}

Even if references to the mocking ${ }^{24}$ of Jesus (Mk 15:20; Mt 27:29; Lk 16:14; 23:35) are taken as instances of derisive laughter, there are only a few references to laughter in the Synoptic Gospels. ${ }^{25}$ Jesus is never portrayed as personally laughing in the Synoptic Gospels, but he did, according to a pronouncement unique to Luke, refer to the laughter of others.

In Luke 6:21b, Jesus refers to those who mourn in the present, pronouncing that they would laugh $(\gamma \varepsilon \lambda \alpha \dot{\alpha} \omega)^{26}$ in the future. Whilst laughing is usually depicted negatively in the LXX ${ }^{27}$ as haughty or foolish, as in 6:25b, according to Luke, Jesus overturns the negative assessment of laughter in this beatitude by portraying it as appropriate to the divine restoration that would result from God's eschatological reversal (Green 1997:267-268). Whilst laughter can be understood in 6:21b as the release of joy as tears are the release of sorrow (Evans 1989:284), or in terms of Halliwell's distinction, as playful laughter, it could also be taken as the derisive laughter of the vindicated that is directed at their vanquished persecutors. As the beatitudes in Luke reflect the reversal of social roles with the eschaton, it seems that $\gamma \varepsilon \lambda \alpha \dot{\omega}$ here refers to the latter.

The beatitude in $6: 21 \mathrm{~b}$ is paired with a contrasting woe in $6: 25 \mathrm{~b}$ that condemns those who laugh in the present by pronouncing that they will in future not only cease to laugh but mourn and weep. Those who laugh (oi $\gamma \varepsilon \lambda \tilde{\omega} v \tau \varepsilon \varsigma$ ),

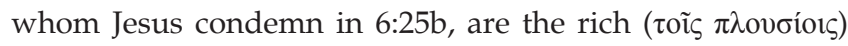
who are boastful about their present lot in life (Evans 1989:288). The reference here is thus not to levity or harmless humour in general but to laughter that is either boastful or

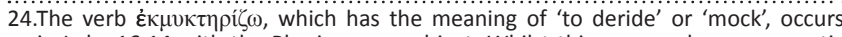
in Luke 16:14 with the Pharisees as subject. Whilst this passage has no synoptic
parallels, Luke's other reference to the mocking of Jesus (23:35) does. In all these episodes, Jesus is depicted as an innocent victim whose honour is actively challenged and diminished.

25.There could be a number of reasons for the general lack of references to laughter in the Synoptic Gospels. According to Lateiner (1974:175), very few laughs are generally recorded for posterity. The ordinary laughter of people could be considered to be sub-historical non-events that are not worth mentioning in written accounts. Or it could simply reflect the historical reality that Jesus neve actually laughed.

26.The verb $\gamma \varepsilon \lambda \alpha \dot{\omega} \omega$ occurs only in Luke $6: 21 b$ and $6: 25 b$ in the New Testament. The cognate noun $\gamma \varepsilon \dot{\varepsilon} \lambda \omega \varsigma$ occurs in James 4:9.

27.In the LXX, $\gamma \varepsilon \lambda \alpha$ á $\omega$ is used to describe how the enemies of Israel laughed (gloated) at the destruction of Jerusalem. In Jewish wisdom literature, it was often used to describe the foolish and their harmful humour (Ec 7:6; Sir. 21:20; 27:13) (Bock 1994:584). The only exception in the LXX is Genesis $21: 6$ where $\gamma \varepsilon \dot{\varepsilon} \lambda \omega \varsigma$ could have 1994:584). The only exception in the LXX is Genesis 21:6 where $\gamma \varepsilon \lambda \omega \varsigma$ could have
the positive sense of laughing with Sarah. It could, however, also refer to the laughter of others at her. According to Marshall (1978:251-252), $\gamma \varepsilon \lambda \alpha \dot{\alpha} \omega$ is used in laughter of others at her. According to Marshall (1978:251-252), $\gamma \varepsilon \lambda \alpha \omega$ is used in
6:21b with a more neutral sense, as it is sometimes used in the Hellenistic world, and with more negative meaning in $6: 25 \mathrm{~b}$. condescending (Bock 1994:584) as it is the laughter of the rich who show no moderation in their accumulation of wealth or their indulgence therein. In 6:21b, the eschatological laughter that Jesus promises to those who mourn in the present reflects the reversal of roles that will occur with the eschaton. The poor and the oppressed will laugh last. The laughter that Jesus envisages is not that of an individual but rather the collective laughter of all who share in the eschatological gift of the kingdom.

In the story of the healing of the daughter of Jairus (Mt 9:24; Mk 5:40; Lk 8:53), the Synoptic Gospels are in agreement that, when Jesus says that the girl is not dead but asleep, he is laughed at by those in attendance. Although Mark does not specify the subject of the imperfect $\kappa \alpha \tau \varepsilon \gamma \dot{\varepsilon} \lambda \omega v$, leaving the possibility that the girl's parents and even Peter, James and John joined in the laughter at the claim of Jesus that the girl was not dead but asleep (France 2002:239-240), it seems more probable that the laughter is to be attributed to the attending mourners. Whilst neither Mark nor Matthew specifies

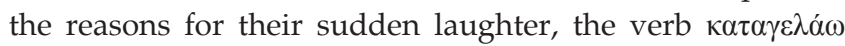
generally denotes derisive laughter (Most 2008:69). The mourners thus do not laugh out of joy or relief with Jesus and the family of the girl but because they find the claim of Jesus to be unbelievable. Luke 8:53, however, states specifically that they laughed because they knew that the girl was dead. Their ridicule expressed their unbelief and their scepticism at the incredulous claim of Jesus. As such it is a deed of public aggression that was an open affront to the honour of Jesus. Jesus is depicted by their laughter as a person whose status as healer, miracle worker and possessor of superior knowledge (the girl is not dead) is not only not recognised and acknowledged by others but openly challenged. Their laughter thus had serious consequences for the honour of Jesus. In response to the challenge of his honour, Jesus heals the girl. He does, however, not laugh with joy with her family or with derision at his sceptical audience.

\section{The laughter of Jesus in Gnostic texts}

In contrast to the depiction of Jesus as laughterless in the Synoptic Gospels, Jesus does laugh in a number of extant Gnostic texts. ${ }^{28}$

\section{The Infancy Gospel of Thomas}

The Infancy Gospel of Thomas is a collection of apocryphal miracle stories purported to have been performed by Jesus prior to his twelfth birthday (Ehrman \& Pleše 2011:3-7). ${ }^{29}$ Whilst some scholars take The Infancy Gospel of Thomas to

28.According to Gilhus (1997:70-71), the Gnostics cultivated laughter in their writings, in which irony, paradox and comedy were used frequently.

29.The Infancy Gospel of Thomas has a complex textual history. It is attested in 14 Greek manuscripts, dating from the 14th and 15th century, that at times differ significantly from each other. It is, however, also known in earlier Syriac copies from the 5 h from the 5 th and 6th century and a fragmentary Latin witness from about the same period (Ehrman \& Pleše 2011:3). Whilst dating the document is difficult, one of the stories in which Jesus meets with a potential teacher is apparently attested in the writings of Irenaeus from around 180 CE (AdV. Haer. 1.20.1) and in the Epistola Apostolorum which was written a few decades earlier (Ehrman \& Pleše 2011:5). In referring to these stories, Irenaeus cites an unnamed heretical writing which was being used by the Marcosians (a group of Christian Gnostics). 
be a Gnostic text to which Irenaeus refers, there is nothing particularly Gnostic about it. The Docetic view of Jesus that is reflected in it does, for instance, not mean that it was undeniably Gnostic as this view of Christ was not uncommon in the eastern provinces of the Roman Empire in the 2nd century (Lapman 2003:131).

Although the Gnostic providence of The Infancy Gospel of Thomas is disputed, its depiction of a laughing Jesus concurs with how he is depicted in other Gnostic texts as there are no less than three instances of laughter in the Greek version of The Infancy Gospel of Thomas. Jesus laughs $(\dot{\varepsilon} \gamma \dot{\varepsilon} \lambda \alpha \sigma \varepsilon)^{30}$ as a child whilst the Jews are giving advice to Zacchaeus (Inf. Gos. Thom. 8.1), who had resigned as his teacher after he had been humbled by Jesus' superior knowledge (Inf. Gos. Thom. 7.1-4). The laugher of Jesus is described as loud ( $\mu \varepsilon \dot{\gamma} \alpha)$ and, combined with the warning in his accompanying words that he had come from above to curse those who are blind (those who do not understand his teaching), leaves his audience silent and fearful. The second reference to laughter is when Jesus is instructed by another teacher who was a friend of Joseph (Inf. Gos. Thom. 15.4). Again the teacher has to admit that he is not worthy to instruct the infant Jesus. On hearing his admission to Joseph, Jesus laughs at him ( $\pi \rho \sigma \sigma \varepsilon \gamma \varepsilon \dot{\lambda} \alpha \sigma \varepsilon v)$. The other reference to laughter is to the laughter ${ }^{31}$ of an infant healed by Jesus (Inf. Gos. Thom. 17.1) and is depicted as the innocent laughter of a child restored to full health by Jesus.

The aim of these infant stories is to explicate the character of Jesus and to demonstrate that he had the same miraculous power and extraordinary wisdom from his birth onward that he later had as an adult (Lapman 2003:130) since ancient writers and readers accepted that a person's character was fixed at birth and that it was revealed in their activities from an early age (Ehrman \& Pleše 2011:3). Although the literary aim of the miracle stories is to portray Jesus as a powerful miracle worker, the references to his laughter specifically depict him as superior to other humans in knowledge and power. Combined with references to the cursing of those who do not acknowledge his superior teaching, it strikes an ominous note that not only emphasises Jesus' abilities but also publically challenges and derides those of others. The laughter of the infant Jesus is certainly not the playful laughter of an innocent child. It is rather the humiliating laughter of one far superior to those he laughs at. To be publically laughed at by a child would have been devastating to the honour of Jesus' failed teachers. In The Infancy Gospel of Thomas, Jesus is thus not the innocent victim of the shaming laughter of others as in the Synoptic Gospels but rather the subject thereof as his laughter has dire consequences for the honour of those against whom it was directed.

\section{The Gospel of Judas}

In the recently published Coptic Gnostic text of The Gospel of Judas, ${ }^{32}$ Jesus laughs on four separate occasions.

30.References are to the Greek text of Ehrman and Pleše (2011).

31.The subject of the verb $\dot{\varepsilon} \gamma \varepsilon \dot{\lambda} \lambda \alpha \sigma \varepsilon v$ could possibly be Jesus and that He thus laughed when the child opened his eyes, or it could refer to the child laughing after it had opened its eyes. Ehrman and Pleše (2011:21) take the child to be the subject.

32.The extant Gospel of Judas, which was discovered in Egypt in 1978, is possibly a Coptic translation of a Greek Gnostic gospel with the same name to which Irenaeus had referred whilst writing around 180 CE (Ehrman \& Pleše 2011:389-390).
The Gospel of Judas consists of a number of conversations between Jesus and his disciples during his last days on earth. In the first encounter of Jesus with the disciples, he comes upon them whilst they are sharing a thanksgiving meal (Gos. Jud. 33). During the meal, they thank God for their bread. When hee sees what they are doing, Jesus laughs at the disciples (Gos. Jud. 34). ${ }^{33}$ According to The Gospel of Judas, he laughs because they had mistakenly assumed that the one who provides their food, the creator of the world, is the God he himself represents. He is, however, not related to the creator God who is an inferior, ignorant deity (Ehrman 2006:89). The disciples respond to his laughter by asking Jesus why he is laughing at them (Gos. Jud. 34) whereas he responds that he is not laughing at them because they are sincere in their lack of understanding of whom they should truly praise (Longenecker 2008:180).

The next morning, Jesus again laughs at his disciples when they ask him about another generation that is greater and holier than they are (Gos. Jud. 36). Once again, his laughter is directed at their lack of understanding (Ehrman 2006:90). The laughter of Jesus, which greatly disturbs the disciples, echoes his words that declare that none of those, who like the disciples were born in the present aeon, will be able to see the greater generation. His laughter serves to emphasise the superior knowledge he has, in which his disciples do not share. The laughter of Jesus can also be seen as subversive and disruptive as it not only causes anxiety amongst his disciples but also constantly undermines their understanding of who he is since it leaves them speechless.

In the third instance where Jesus laughs, he is laughing at Judas who wants to tell him the great vision that he has had (Gos. Jud. 44). The laughter of Jesus here mocks Judas and emphasises the difference between his superior knowledge and that of Judas. Although Judas is not lacking a spark of the divine, like the other disciples, he has not yet understood the mysteries that Jesus has to reveal.

The last instance of laughter occurs after Jesus had discussed the destruction of the wicked with Judas (Gos. Jud. 55). The laughter of Jesus is here not directed at Judas but at the six stars and five warriors (the rulers of this world) who do not understand that they will be destroyed along with their creatures (Ehrman 2006:96).

According to Most (2008:70), Jesus' laughter in The Gospel of Judas indicates his awareness of the difference between the superiority of his knowledge and the ignorance of his interlocutors. His derisive laughter serves to indicate their appropriate relation to Jesus regarding knowledge. Whereas his knowledge is complete, theirs is at best partial. Both Judas and the disciples understand the laughter of Jesus to be negative. They are troubled by it and even react with anger at his derisive laughter (Gos. Jud. 34). Jesus, however, twice denies that he is laughing at them (Gos. Jud. 34; 55). He apparently has a measure of sympathy for their lack of 33. References are to the relevant section in the English text of Ehrman and Pleše (2011). 
knowledge as he asserts that the disciples and Judas are in thrall to a lesser God and are thus unable to transcend their limitations (Most 2008:71). Whilst the laughter of Jesus in The Gospel of Judas could at times be understood to be compassionate, it predominantly serves to underline the superiority of Jesus in relation to his disciples and Judas. It is also not playful or innocent as it causes great anxiety and uncertainty amongst his disciples (Longenecker 2008:180181).

\section{The Coptic Apocalypse of Peter}

The Coptic Apocalypse of Peter is a pseudonymous Gnostic Christian tractate found in the Nag Hammadi library. ${ }^{34}$ In it, the Saviour and Peter are situated in the temple before the crucifixion where Peter receives a vision about the arrest and trial of the Saviour. The vision is followed by an explanatory revelation wherein the truth about the crucifixion of Jesus is revealed to Peter.

In the complicated explanatory revelation, Peter sees two figures. ${ }^{35}$ One is depicted as laughing whilst sitting on a tree whilst the other is being physically assaulted and crucified (Apoc. Peter 81). ${ }^{36}$ The Saviour reveals to Peter that the person in the tree, who is laughing, is the living Jesus. He is the first in spirit, who laughs at his enemies for their lack of perception (Apoc. Peter 83) since they remain blind, as they were when born, to the truth. It is this all-knowing spirit filled with radiant light who is the living Saviour who reveals the mysteries of the crucifixion to Peter. The other one, who is being crucified, is only the mortal shell of his immortal being. Peter is, furthermore, reassured by the Saviour that he has been entrusted with insight into the mystery that the one who was crucified was the first-born in the home of demons, who lived in a corruptible vessel and whom the god of this world killed by means of the cross.

The Gnostic character of The Coptic Apocalypse of Peter is evident from a radical dualism that distinguishes between two levels of reality which closely resemble each other but are opposites. The one is material, mortal and counterfeit; the other is spiritual, immortal and true. It also makes a clear distinction between the physical Jesus who died on the cross, whom some Christians mistakenly believe has been physically restored, and the heavenly, living, Christ who is spiritual and who was not crucified. The laughter of the heavenly Christ reveals the foolishness of those who thought they were crucifying him and serves to devaluate the beliefs of those who are blind and deaf in that they are

34.The only extant text of The Apocalypse of Peter is a 4 th-century Coptic translation of the original Greek document. The provenance of the Greek document is unclear. It could have been written in the eastern provinces of Asia late in the 2 nd century (Lapland 2003:106-107) or in the 3rd century when the distinction between emerging orthodoxy and heresy was more clearly drawn (Brashler \& Bullard 1996:372). Until the discovery of the Nag Hammadi library, the Gnostic story of the laughing Jesus who escaped being crucified was known only from Irenaeus and Epiphanius who attributed it to the Gnostic teacher Basilides (Dart 1976:108).

35.The Coptic Apocalypse of Peter has the polymorphic appearances of three 'Christ' figures - the living Saviour who explains the revelation to Peter, the fleshly likeness figures - the living Saviour who explains the revelation to Peter, the fleshly likeness
of Christ that is crucified and the real Christ that watches the crucifixion and laughs (Lapman 2003:106).

36. References are to the translation of 'The apocalypse of Peter' by James Brasher and Roger A. Bullard in the Nag Hammadi Library in English. only able to recognise material reality. It can be described as consequential laughter that serves to highlight his superiority of understanding.

\section{The Second Treatise of the Great Seth}

The Second Treatise of the Great Seth ${ }^{37}$ is a revelation dialogue allegedly delivered by Jesus to an audience of Gnostic believers (described as the 'perfect and incorruptible ones'). The treatise briefly describes the story of the commissioning of the Saviour, his descent to earth, his encounter with the worldly powers and apparent crucifixion and his return to the pleroma (Bullard \& Gibbons 1996:362).

It is during the description of the crucifixion that Jesus is depicted as laughing at the ignorance of his supposed executioners who think that they have killed him. ${ }^{38}$ Laughter in The Second Treatise of the Great Seth is not confined to the crucifixion scene. After the Creator God (the Archon) had boasted that he is God and that there is no one beside him, the narrator (later identified as Christ in Treat. Seth 65) responds with laughter at his empty boast (Treat. Seth 64).

In The Second Treatise of the Great Seth, Jesus also calls a number of prominent figures from the past (Adam, Abraham, Isaac, David, Solomon, the twelve Prophets and John the Baptist) 'laughingstocks' since they never knew the truth about Christ (Treat. Seth 62-64). The possibility that this section initially formed a counter-litany mocking the belief of the orthodox who worship a lesser god gives the impression that laughter and mockery was a trait of some Gnostics during their history (Dart 1976:110).

\section{Conclusion}

In contrast to the contemporary quest for a Jesus who laughs easily and often, the Jesus depicted in the Synoptic Gospels is not only without laughter but the object of the derogatory laughter of others. The consequential laughter directed at Jesus in Mark 5:40 (Mt 9:24; Lk 8:53) serves as a serious public challenge to Jesus' claim to superior knowledge (he alone knows that the daughter of Jairus is not dead) and the honour he thereby claims. Within the context of the GrecoRoman world, the reference to the laughter of others is a concise but extremely serious challenge to the honour of Jesus, a challenge to which he had to respond. Only proof that the girl was indeed not dead could silence the derogatory laughter of the onlookers.

The absence of both consequential and playful laughter with Jesus as subject seemingly reflects the theological understanding of the Synoptic authors that the importance of the mission of Jesus, and the gravity of his suffering, was incompatible with any form of humour or references to laughter (Most 2008:69). They apparently did not wish to risk

37.A number of Gnostic texts have been gathered under the name Sethian as Seth the son of Adam and Eve, has a prominent place therein. Several Gnostic laughter myths are found in this Sethian group of texts (Gilhus 1997:70).

38. References are to the translation of Roger A. Bullard and Joseph A. Gibbons (1996) 'The Second Treatise of the Great Seth' in the Nag Hammadi Library in English. 
the negative connotations that playful laughter (a lack of selfcontrol or balance and frivolity) and consequential laughter (the intentional public humiliation of others) had in the Greco-Roman world. Whilst all laughter was not necessarily seen as negative in the Greco-Roman world, rethors had to be careful in their use of laughter as it could negatively impact on an audience's understanding of the subject thereof. In contrast to some contemporary interpreters, the writers of the Synoptic Gospels apparently did not see laughter and humour as essential aspects of the humanity and character of Jesus. As explained by Jesus (Lk 6:21b, 25b), laughter is, however, an appropriate expression for the redeemed after the eschaton. All laughter is thus not evaluated negatively.

The primary difference between the references to laughter in the Synoptic and the Gnostic texts surveyed is that, whereas Jesus is depicted as the object of derisive laughter in the Synoptic Gospels, the opposite is true in the Gnostic texts. The Gnostic documents have no qualms in depicting Jesus as openly laughing at his teachers, followers or enemies. No one seems to be spared the derisive laughter of the Gnostic Jesus. Although not all references to the laughter of Jesus in the Nag Hammadi library is necessarily derisive, ${ }^{39}$ they are all usually responses to the lack of knowledge or insight of others (cf. Dart 1976:111). By laughing at their answers and questions, the Gnostic Jesus at times publically puts both his enemies and followers to shame.

The context of many of the references to the laughter of Jesus in the Gnostic literature is also noteworthy as they often occur in regards to his crucifixion. Again, in these Gnostic texts, the laughter of Jesus is not seen as a characteristic that emphasises his human nature, to which contemporary readers would be able to relate (i.e. he is human because he laughs), but rather the opposite in that he can laugh in the face of death as he does not inhabit a physical body that can be killed (or is able to deceive his enemies in killing another in his place).

If the aim of the Gnostic writings was to serve intentionally as a correction of the depiction of Jesus in the Synoptic Gospels and within orthodox Christianity ${ }^{40}$ it is clear that they did not describe a laughing Jesus in order to make him more human. In a number of Gnostic texts, it is precisely the dualism, that emphasises the separation of the spiritual from the material and non-Gnostics' failure to understand this distinction, that serves as basis for most examples of Gnostic laughter (Gilhus 1997:71). Nor did Gnostic texts just want to change Jesus from the object to the subject of derisive laughter in order to underline his superiority in regards to his enemies and followers. ${ }^{41}$

39. For instance, when reacting to a question of John in The Apocryphon of John, Jesus smiled at him (Ap. John 13) but still gave a reply. The reply of Jesus can be taken as ironic and thus a criticism of any non-Gnostic understanding (Gilhus 1997:70-71). In The Sophia of Jesus Christ, Jesus also laughs at the perplexity of his disciples when they are afraid and unsure after he had greeted them (Soph. Jes. Chr. 92).

40.The gnostic texts' depiction of the laughter of Jesus is a characteristic example of their tendency to reinterpret a whole series of tenets basic to the depiction of Jesus in the Synoptic Gospels (Most 2008:72).

41.In a number of Gnostic texts, it is not only the patriarchs and the prophets who are laughed at but Jahweh himself. Whilst God laughs at humans in the Old Testament, in the Gnostic myths, human beings laugh at Jahweh (Gilhus 1997:71-73).
The laughter of Jesus in the Gnostic writings rather has a disruptive and conformational rhetorical aim as his laughter is primarily directed at those who misunderstand him. In the Gnostic writings, the ones who misunderstand him the most are his own followers, who think they know who he is but who do not possess the true knowledge of his identity. The description of the laughter of Jesus emphasises that the opponents (orthodox Christianity) of the Gnostic movement had misunderstood him (especially in regard to the meaning of the crucifixion) whilst only the Gnostics had the true knowledge of who he was (cf. Ehrman 2006:111-112). The laughter of Jesus thus had a disruptive function in regard to orthodox Christianity and a conformational function in regard to the Gnostics themselves. It was the same sort of critical laughter used in the rhetoric of the 2nd century (Gilhus 1997:70). It was thus not playful, but consequential, as it wanted to give the Gnostic Jesus the last laugh.

\section{Acknowledgements Competing interests}

The author declares that he has no financial or personal relationship(s) which may have inappropriately influenced him in writing this article.

\section{References}

Apte, M.L., 1985, Humor and laughter: An anthropological approach, Cornell University Press, London.

Bednarz, T., 2009, 'Humor-neutics: Analyzing humor and humor functions in the synoptic gospels', PhD thesis, Brite Divinity School, Texas Christian University.

Bennet, D.J., 2011, 'The humor of Christ: A different methodological approach', Humor 24, 349-356.

Berger, P.L., 1997, Redeeming laughter: The comic dimension of human experience, Walter de Gruyter, New York. http://dx.doi.org/10.1515/9783110810660

Billing, M., 2005, Laughter and ridicule: Toward a social critique of humour, SAGE Publications, London.

Bock, D.L., 1994, Luke 1:1-9:51, Baker Academic, Grand Rapids. (Baker Exegetical Commentary on the New Testament.)

Brashler, J. \& Bullard, R.A., 1996, 'The apocalypse of Peter', in J.M. Robertson (ed.) The Nag Hammadi Library in English, 4th rev. edn., pp. 372-378, Brill, New York.

Bullard, R.A. \& Gibbons, J.A., 1996, 'The Second Treatise of the Great Seth', in J.M. Robertson (ed.), The Nag Hammadi Library in English, 4th rev. edn., pp. 362-371, Brill, New York.

Dart, J., 1976, The laughing Savior: The discovery and significance of the Nag Hammandi Gnostic Library, Harper \& Row Publishers, London. PMCid:PMC274368

Ehrman, B.D., 2006, The Lost Gospel of Judas Iscariot: A new look at betrayer and betrayed, Oxford University Press, Oxford.

Ehrman, B.D. \& Pleše, Z., 2011, The apocryphal gospels: Texts and translations, Oxford University Press, Oxford.

Evans, C.F., 1989, Luke 1:1-9:20, Word Incorporated, Dallas. (Word Biblical Commentary 35A.)

France, R.T., 2002, The Gospel of Mark, Eerdmans, Grand Rapids. (New International Greek Testament Commentary.)

Geybels, H., 2011, 'The redemptive power of humour in religion', in W. van Herck \& H. Geybels (eds.), Humour and religion: Challenges and ambiguities, pp. 11-21, Bloomsbury Academic, London. (Continuum Religious Studies.)

Gilhus, I.S., 1997, Laughing Gods, weeping virgins, Routledge, New York. http://dx.doi. org/10.4324/9780203411605

Green, J.B., 1997, The Gospel of Luke, Eerdmans, Grand Rapids. (New International Commentary on the New Testament.)

Halliwell, S., 1991, 'The uses of laughter in Greek culture', The Classical Quarterly 41, 279-296. http://dx.doi.org/10.1017/S0009838800004468

Halliwell, S., 2008, Greek laughter: A study of cultural psychology from Homer to Early Christianity, Cambridge University Press, Cambridge. http://dx.doi.org/10.1017/ CBO9780511483004

Hand, K., 2013, 'A wicked sense of humor', Theology Today 70, 119-127. http://dx.doi. org/10.1177/0040573613484753 
Kidd, S., 2011, 'Laughter interjections in Greek comedy', The Classical Quarterly 61, 445-459.

Krosney, H., 2006, The Lost Gospel: The quest for the Gospel of Judas Iscariot, Nationa Geographic, Washington. http://dx.doi.org/10.1017/S0009838811000115

Lapman, F., 2003, An introduction to the New Testament Apocrypha, T \& T Clark, Sheffield.

Lateiner, D., 1974, 'No laughing matter: A literary tactic in Herodotus', Transactions of the Philological Association 107, 173-182. http://dx.doi.org/10.2307/284034

Longenecker, B.W., 2008, 'A humorous Jesus? Orality, structure and characterisation in Luke 14:15-24 and beyond', Biblical Interpretation 16, 179-2004. http://dx.doi. org/10.1163/156851508X262966

Louw, J.P. \& Nida, E.A., 1989, Greek-English lexicon of the New Testament: Based on semantic domains, vol. 1 \& 2, United Bible societies, New York.
Marshall, I.H., 1978, Commentary on Luke, Eerdmans, Grand Rapids. (New International Commentary on the New Testament.)

Most, G.W., 2008, 'The Judas of the Gospels and the Gospel of Judas', in M. Scopello (ed.), The Gospel of Judas in context: Proceedings of the first international conference on the Gospel of Judas, pp. 69-80, Brill Academic Publications, Leiden. (Nag Hammadi and Machaean Studies.) http://dx.doi.org/10.1163/ ej.9789004167216.i-404.25

Perks, L.G., 2012, 'The ancient roots of humor theory', Humor 25, 119-132.

Shelly, C., 2003, 'Plato on the psychology of humor', Humor 16, 351-367.

Taels, J., 2011, 'Humour as practical wisdom', in W. van Herck \& H. Geybels (eds.), Humour and religion: Challenges and ambiguities, p. 23, Bloomsbury Academic, London. (Continuum Religious Studies.)

Wickberg, D., 1998, The sense of humour, Cornell University Press, Ithaca. 